\title{
Legal counseling for narcotics abuse prevention through village regulation legislation in village of Dagang Kerawan district of Tanjung Morawa regency of Deli Serdang
}

\author{
Siti Nurahmi Nasution ${ }^{1 *}$, Rosnidar Sembiring ${ }^{1}$, Eva Syahfitri Nasution ${ }^{2}$, Robert ${ }^{3}$, M. Hadyan \\ Yunhas Purba ${ }^{1}$ \\ ${ }^{1}$ Civil Law Department, Faculty of Law, Universitas Sumatera Utara, Medan, Indonesia \\ ${ }^{2}$ Criminal Law Department, Faculty of Law, Universitas Sumatera Utara, Medan, Indonesia \\ ${ }^{3}$ Economic Law Department, Faculty of Law, Universitas Sumatera Utara, Medan, Indonesia \\ *Email: siti.nstnurahmi@gmail.com
}

\begin{abstract}
The number of narcotics abuse cases in Indonesia is increasing every year, so that it has become a national issue. The victims of narcotics abuse are just not spread in urban areas, yet the village areas are not excluded from the spread. Narcotics circulation also does not regard age, social level, and even gender. It is not seldom that the main target of narcotics circulation is the young generations; this fact indeed becomes a concern for every element in Indonesia, considering young generations are the pole of hope of a nation. The village is a strategic area for the smuggling and circulation of narcotics abuse. To overcome the circulation and abuse of narcotics, therefore anticipation through policy and prevention strategy by legislating a legal rule according to a local government's authority. The lack of knowledge in formulating policy through legislation as a legal rule for preventing narcotics circulation and abuse constitutes this counsel to Dagang Kerawan Village people. By providing legal counselling about narcotics abuse prevention through village regulation legislation, it is hoped to prevent, reduce, and eradicate narcotics abuse and circulation, especially in villages.
\end{abstract}

Keyword: narcotics, village, village regulation

\begin{abstract}
Abstrak
Kasus penyalahgunaan narkoba di Indonesia semakin meningkat setiap tahunnya, sehingga hal tersebut dijadikan masalah nasional. Korban penyalahgunaan narkoba tidak saja merambah daerah perkotaan, namun wilayah pedesaan juga tidak luput menjadi sasaran. Peredaran narkoba juga tidak memandang usia, strata sosial bahkan jenis kelamin. Tidak jarang sasaran utama peredaran narkoba adalah para generasi muda, hal ini jelas menjadi persoalan bagi seluruh elemen yang ada di Indonesia, mengingat generasi muda adalah tonggak harapan suatu negara. Desa merupakan wilayah strategis untuk jalur penyelundupan dan penyebaran penyalahgunaan serta peredaran gelap narkoba, maka desa harus menjadi garda terdepan untuk melakukan pencegahan penyalahgunaan dan peredaran gelap narkoba. Untuk menanggulangi penyalahgunaan dan peredaran gelap narkoba, perlu dilakukan antisipasi melalui kebijakan dan strategi pemberantasan yang efektif melalui penetapan payung hukum sesuai dengan kewenangan daerah.Keterbatasan pengetahuan dalam menyusun kebijakan berupa regulasi sebagai payung hukum pencegahan penyalahgunaan dan peredaran gelap narkoba menjadi dasar dilakukannya pengabdian kepada masyarakat di Desa Dagang Kerawan. Dengan memberikan penyuluhan hukum pencegahan penyalahgunaan narkoba melalui pembentukan peraturan desa diharapkan dapat mencegah, mengurangi dan memberantas penyalahgunaan dan peredaran gelap narkoba terutama di desa.
\end{abstract}

Kata Kunci: narkoba, desa, peraturan desa 


\section{PENDAHULUAN (INTRODUCTION)}

Dalam Kamus Besar Bahasa Indonesia (KBBI), Narkoba adalah akronim dari kata Narkotika, Psikotropika dan Obat berbahaya lainnya. KBBI mengistilahkan narkoba atau narkotika adalah obat yang dapat menenangkan syaraf, menghilangkan rasa sakit, menimbulkan rasa mengantuk atau merangsang. Secara positif, penggunaan narkoba di satu sisi merupakan obat atau bahan yang bermanfaat di bidang pengobatan atau pelayanan kesehatan dan pengembangan ilmu pengetahuan. Akan tetapi pada sisi lainnya dapat menimbulkan ketergantungan yang sangat merugikan dan membahayakan kesehatan apabila disalahgunakan atau digunakan tanpa pengendalian dan pengawasan yang ketat dan seksama.

Kejahatan narkoba merupakan kejahatan international (international crime), kejahatan yang terkoorganisir (organized crime), mempunyai jaringan yang luas, mempunyai dukungan dana yang besar dan sudah menggunakan teknologi yang canggih. Narkoba mempunyai dampak negatif yang sangat luas; baik secara fisik, psikis, ekonomi, sosial, budaya, hankam, dan lain sebagainya. Bila penyalahgunaan narkoba tidak diantisipasi dengan baik, maka akan rusak bangsa dan negara ini.

Pembentukan Undang-Undang Nomor 35 Tahun 2009 tentang Narkotika merupakan suatu upaya pemerintah Indonesia untuk mengatur tata cara mengimpor, mengekspor, memproduksi, menanam, menyimpan, mengedarkan, dan/atau menggunakan narkotika serta bagaimana pengendalian dan pengawasan narkoba melalui sistem hukum pidana jika melakukan pelanggaran terhadap UU tersebut sebab sangat mengancam ketahanan nasional.

Kasus penyalahgunaan narkoba di Indonesia semakin meningkat setiap tahunnya, sehingga hal tersebut dijadikan masalah nasional. Korban penyalahgunaan narkoba tidak saja merambah daerah perkotaan, namun wilayah pedesaan juga tidak luput menjadi sasaran. Peredaran narkoba juga tidak memandang usia, strata sosial bahkan jenis kelamin. Tidak jarang sasaran utama peredaran narkoba adalah para generasi muda, hal ini jelas menjadi persoalan bagi seluruh elemen yang ada di Indonesia, mengingat generasi muda adalah tonggak harapan suatu negara. Kenyataannya bahaya narkoba menjadi momok yang menakutkan bagi bangsa Indonesia, sehingga kampanye anti narkoba terus dimaksimalkan. Di Indonesia, kematian akibat penyalahgunaan narkoba mencapai 37 sampai dengan 40 orang setiap harinya sehingga Indonesia termasuk negara darurat narkoba. Jika hal tersebut terus dibiarkan akan menyebabkan terjadinya loss generation atau suatu keadaan dimana negeri ini tiada lagi manusia muda yang hidupnya normal baik fisik maupun mentalnya sebagai penerus kepemimpinan bangsa ini sebab telah dirusak dan menjadi korban penyalahgunaan narkoba. Oleh karena itu, upaya pencegahan dan pemberantasan penyalahgunaan dan perdaran gelap narkoba harus terus dilakukan secara sistematis dan berkesinambungan.

Desa menjadi wilayah strategis untuk jalur penyelundupan dan penyebaran penyalahgunaan serta peredaran gelap narkoba, maka desa harus menjadi garda terdepan untuk melakukan pencegahan penyalahgunaan dan peredaran gelap narkoba. Untuk menanggulangi penyalahgunaan dan peredaran gelap narkoba, perlu dilakukan antisipasi melalui kebijakan dan strategi pemberantasan yang efektif melalui penetapan payung hukum sesuai dengan kewenangan daerah.

Keterlibatan pemerintah desa dalam memerangi narkoba melalui pencegahan penyalahgunaan dan peredaran gelap narkoba menjadi sebuah strategi yang tepat karena Desa sebagaimana diatur dalam Undang-Undang Nomor 6 Tahun 2014 mempunyai kewenangan dalam membina masyarakat desa untuk berhak mendapatkan pengayoman serta perlindungan dari gangguan ketenteraman dan ketertiban di Desa agar terciptanya situasi yang aman, nyaman, dan tenteram di Desa.

Berdasarkan pengaturannya, Kepala Desa berkewajiban untuk melakukan pembinaan ketenteraman dan ketertiban masyarakat desa sekaligus juga memberdayakan masyarakat desa termasuk dalam pencegahan penyalahgunaan dan peredaran gelap narkoba. Mengingat pencegahan penyalahgunaan dan peredaran gelap narkoba adalah merupakan salah satu kewenangan pemerintah desa dalam mewujudkan kondisi tenteram dan tertib maka kegiatan ini perlu dirumuskan dalam program prioritas desa melalui pembentukan Peraturan Desa. 
Berdasarkan keterangan Kepala Desa Dagang Kerawan, penyalahgunaan dan peredaran gelap narkoba sering terjadi di wilayahnya serta belum ada ketentuan hukum di yang dibentuk oleh Pemerintah Desa dalam bentuk Peraturan Desa yang mengatur tentang masalah tersebut. Oleh karena itu perlu dilakukan strategi yang tepat dalam mencegah serta memberantas penyalahgunaan dan peredaran gelap narkoba sesuai dengan program pemerintah salah satunya melalui pembentukan Peraturan Desa.

Keterbatasan pengetahuan dalam menyusun kebijakan berupa regulasi sebagai payung hukum pencegahan penyalahgunaan dan peredaran gelap narkoba menjadi dasar dilakukannya pengabdian kepada masyarakat di Desa Dagang Kerawan. Dengan memberikan penyuluhan hukum pencegahan penyalahgunaan narkoba melalui pembentukan peraturan desa diharapkan dapat mencegah, mengurangi dan memberantas penyalahgunaan dan peredaran gelap narkoba terutama di desa.

\section{METODE PELAKSANAAN (METHODS)}

Kegiatan pengabdian kepada masyarakat ini akan dilaksanakan di Desa Dagang Kerawan, Kecamatan Tanjung Morawa, Kabupaten Deli Serdang, Provinsi Sumatera Utara. Untuk mendukung kegiatan ini, perlu diselesaikan dan disinergikan bersama antara mitra dengan sivitas akademika. Kegiatan dilakukan dalam dua tahapan, meliputi tahap persiapan dan tahap pembimbingan. Strategi pencapaian target dan luaran disajikan pada Gambar 1.

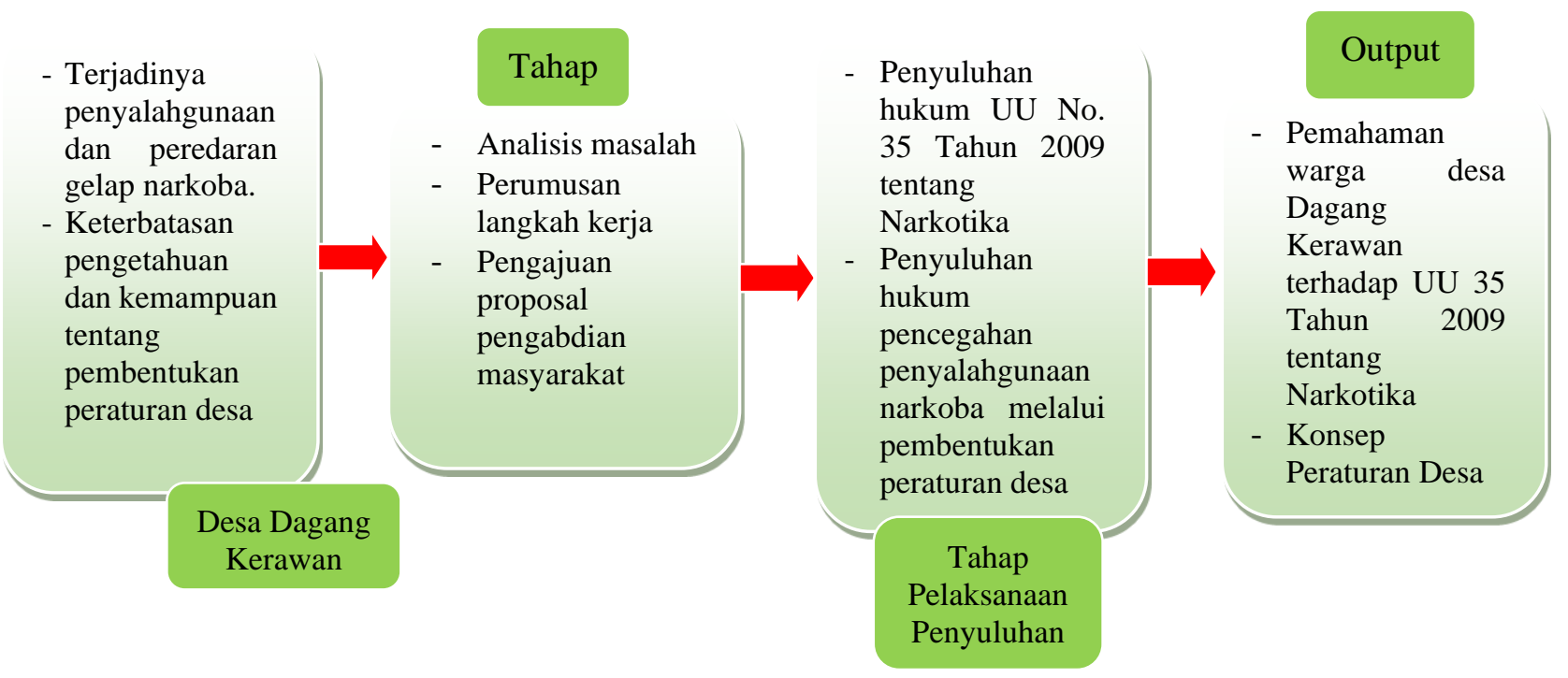

Gambar 1. Diagram Strategi Pemecahan Masalah Mitra

Untuk mendukung strategi pemecahan masalah mitra ini, maka ada beberapa hal yang akan dilakukan antara lain:

a. Tahapan persiapan

Pada tahapan ini, tim pengabdian masyarakat melakukan analisa yang terdapat di Desa dagang Kerawan Kecamatan Tanjung Morawa Kabupaten Deli Serdang. Setelah menganalisis permasalahan yang ada, tim pengabdian masyarakat bersama mitra sepakat untuk melakukan langkah kerja yang akan dilakukan di desa tersebut.

b. Tahapan pelaksanaan penyuluhan

Setelah tahap persiapan selesai dilaksanakan, maka akan dilakukan beberapa tahapan pelaksanaan penyuluhan hukum pencegahan penyalahgunaan narkoba melalui pembentukan peraturan desa. Adapun tahap pelaksanaan penyuluhan ini dilakukan dengan memberikan pemahaman kepada warga desa Dagang Kerawan tentang: 
1) Materi umum terhadap narkoba sebagaimana yang diatur dalam UU Nomor 35 Tahun 2009 tentang Narkotika

2) Materi umum tentang dampak dari penyalahgunaan narkoba;

3) Strategi pencegahan penyalahgunaan narkoba yang dapat dilakukan oleh pemerintah desa; dan

4) Materi umum tentang teknik penyusunan dan pembentukan peraturan desa.

\section{HASIL DAN PEMBAHASAN (RESULT AND DISCUSSION)}

Ketua Tim Pengabdian menjelaskan kepada masyarakat Desa Dagang Kerawan tentang bahaya yang secara nyata mengancam generasi muda Indonesia akibat penyalahgunaan narkoba. Oleh karenanya, Tim Pengabdian sebagai dosen USU memiliki tanggung jawab moral sebagai bagian dari Tri Darma Perguruan Tinggi untuk memberikan pemahaman kepada masyarakat Desa Dagang Kerawan terkait bahaya dan aspek hukum dari penyalahgunaan narkoba. Hal ini menjadi penting karena ancaman nyata dari narkoba tidak saja ada di kota besar, untuk wilayah desa pun sudah tidak luput dari incaran para pengedar narkoba. Kepala Desa Dagang Kerawan juga menyatakan bahwa sudah terdapat beberapa kasus penyalahgunaan narkoba di Desa Dagang Kerawan dengan pelaku yang rata-rata masih berusia di bawah 30 tahun. Pernyataan dari Kepala Desa tersebut merupakan bukti bahwa Desa Dagang Kerawan tidak luput dari ancaman bahaya narkoba. Melalui penyuluhan hukum ini diharapkan masyarakat dapat semakin waspada dan bertindak preventif terhadap ancaman narkoba yang semakin nyata di lingkungan Desa Dagang Kerawan. Perangkat Desa dan masyarakat setuju dengan ancaman dari narkoba pada lingkungan Desa Dagang Kerawan dan berkomitmen secara bersama-sama untuk memerangi narkoba di wilayah mereka.

Pada sesi berikutnya, Tim Pengabdian mendiskusikan dengan Perangkat Desa terkait Rancangan Peraturan Desa tentang Pencegahan dan Pemberantasan Penyalahgunaan Narkoba. Kepala Desa Dagang Kerawan menyambut positif rancangan peraturan desa tersebut. Diharapkan rancangan peraturan desa yang disampaikan oleh Tim Pengabdian dapat dibahas oleh Perangkat Desa untuk dilahirkan sebagai Peraturan Desa yang sifatnya mengikat bagi seluruh penduduk pada Desa Dagang Kerawan. Dengan demikian, masyarakat Desa Dagang Kerawan akan memiliki suatu landasan hukum yang kuat untuk mendukung tekad mereka guna mencegah dan memberantas penyebaran narkoba di wilayahnya.

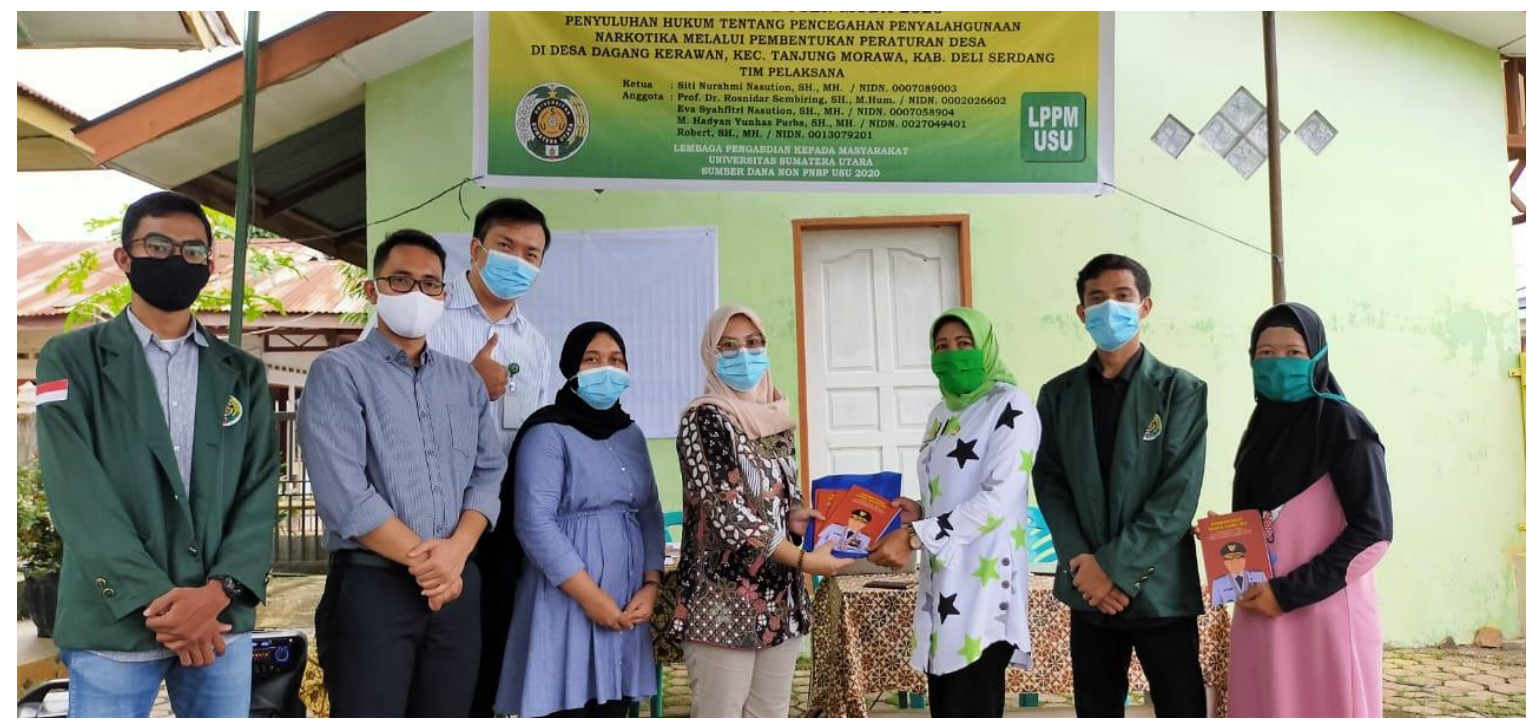

Gambar 3. Foto Bersama Tim Pengabdian dengan Kepala Desa Dagang Kerawan 


\section{KESIMPULAN (CONCLUSION)}

Berdasarkan hasil pelaksanaan Pengabdian kepada Masyarakat ini, maka terdapat dua hal yang bisa ditarik sebagai kesimpulan, yakni:

a. Kegiatan penyuluhan hukum ini memberikan manfaat yang positif bagi masyarakat pada Desa Dagang Kerawan, Kecamatan Tanjung Morawa, Kabupaten Deli Serdang. Masyarakat sekitar menjadi lebih memahami tentang jenis-jenis narkoba dan dampak negatifnya bagi kesehatan fisik dan mental dari pecandunya. Di samping itu, masyarakat juga mendapat pemahaman tentang aspek hukum terkait penyalahgunaan narkoba. Dengan demikian, diharapkan timbul kesadaran bagi masyarakat untuk memerangi dan melaporkan kepada pihak yang berwajib terkait segala bentuk penyalahgunaan nakorba di Desa Dagang Kerawan.

b. Kegiatan penyuluhan hukum ini juga memberikan manfaat yang positif bagi Pemerintahan Desa Dagang Kerawan. Kepala Desa Dagang Kerawan mengapresiasi kegiatan ini karena Pemerintahan Desa Dagang Kerawan memperoleh pemahaman dan gambaran bagaimana merancang suatu peraturan desa terkait pencegahan penyalahgunaan narkoba yang sesuai dengan ketentuan pembentukan peraturan perundang-undangan yang benar di Indonesia. Dengan demikian diharapkan Pemerintahan Desa Dagang Kerawan akan dapat membentuk Peraturan Desa tentang Pencegahan Penyalahgunaan Narkoba sebagai upaya preventif terhadap segala bentuk penyalahgunaan narkoba di wilayah Desa Dagang Kerawan.

\section{UCAPAN TERIMAKASIH (ACKNOWLEDGMENTS)}

Artikel ini merupakan luaran dari Program Pengabdian kepada Masyarakat yang dibiayai oleh dana NON PNBP Universitas Sumatera Utara. Oleh karena itu, diucapkan terima kasih kepada Rektor Universitas Sumatera Utara atas dukungan dana dan fasilitas yang diberikan. Terima kasih juga diucapkan kepada Mitra dalam kegiatan pengabdian ini.

\section{DAFTAR PUSTAKA}

Eleanora, Fransiska Novita. (2011). Bahaya Penyalahgunaan Narkoba serta Usaha Pencegahan dan Penanggulangannya (Suatu Tinjauan Teoritis). Jurnal Hukum. Vol. XXV No. 1 pp. 439-52

Tim Penyusun Modul. (2019). Modul Narkotika. Jakarta: Badan Pendidikan dan Pelatihan Kejaksaan Republik Indonesia.

Deputi Bidang Pencegahan BNN RI Direktorat Advokasi. Awas Narkoba Masuk Desa Dalam Rangka Mewujudkan Desa Bersih Narkoba (Desa Bersinar). Jakarta: Badan Narkotika Nasional Republik Indonesia.

Republik Indonesia. Undang-Undang Nomor 35 Tahun 2009 tentang Narkotika.

Republik Indonesia. Undang-Undang Nomor 6 Tahun 2014 tentang Desa.

Siregar,Wahyudi Aulia. (2018). BNN: 40 Orang di Indonesia Meninggal Setiap Hari Karena Narkoba. Diakses dari https://news.okezone.com/read/2018/05/12/340/1897351/bnn-40orang-di-indonesia-meninggal-setiap-hari-karena-narkoba 